\title{
An In Vitro Model of Diabetic Retinal Vascular Endothelial Dysfunction and Neuroretinal Degeneration
}

\author{
Qiyun Wang $\mathbb{D}^{1,2}$ Xinyuan Zhang $\mathbb{D}^{1,2}$ Kaiyue Wang, ${ }^{1}$ Ling Zhu $\mathbb{D}^{3},{ }^{3}$ Bingjie Qiu $\mathbb{D}^{1,2}$ \\ Xiaosi Chen $\mathbb{D}^{1},{ }^{1,2}$ Xiao Lin, ${ }^{1}$ and Yao Nie $\mathbb{B}^{1,2}$ \\ ${ }^{1}$ Beijing Institute of Ophthalmology, Tongren Eye Center, Beijing Tongren Hospital, Capital Medical Univeristy, Beijing, China \\ ${ }^{2}$ Beijing Retinal and Choroidal Vascular Diseases Study Group, China \\ ${ }^{3}$ Save Sight Institute, Department of Ophthalmology, Faculty of Medicine and Health, The University of Sydney, Sydney, Australia
}

Correspondence should be addressed to Xinyuan Zhang; mmzxy2010@163.com

Received 19 August 2021; Accepted 9 October 2021; Published 10 November 2021

Academic Editor: Honghua Yu

Copyright ( 2021 Qiyun Wang et al. This is an open access article distributed under the Creative Commons Attribution License, which permits unrestricted use, distribution, and reproduction in any medium, provided the original work is properly cited.

\begin{abstract}
Background. Diabetic retinopathy (DR) is a leading cause of blindness in working-age populations. Proper in vitro DR models are crucial for exploring pathophysiology and identifying novel therapeutic targets. This study establishes a rational in vitro diabetic retinal neuronal-endothelial dysfunction model and a comprehensive downstream validation system. Methods. Human retinal vascular endothelial cells (HRMECs) and retinal ganglion cells (RGCs) were treated with different glucose concentrations with mannitol as matched osmotic controls. Cell proliferation and viability were evaluated by the Cell Counting Kit-8. Cell migration was measured using a transwell migration assay. Cell sprouting was assessed by a tube formation assay. The VEGF expression was assessed by ELISA. RGCs were labeled by neurons and RGC markers TUJ1 and BRN3A for quantitative and morphological analysis. Apoptosis was detected using PI/Hoechst staining and TUNEL assay and quantified by ImageJ. Results. Cell proliferation and migration in HRMECs were significantly higher in the $25 \mathrm{mM}$ glucose-treated group $(p<0.001)$ but lower in the $50 \mathrm{mM}$ and $100 \mathrm{mM}$ groups $(p<0.001)$. The permeability and the apoptotic index in HRMECs were statistically higher in the $25 \mathrm{mM}, 50 \mathrm{mM}$, and $100 \mathrm{mM}$ groups $(p<0.05)$. The tube formation assay found that all the parameters were significantly higher in the $25 \mathrm{mM}$ and $50 \mathrm{mM}$ groups $(p<0.001)$ concomitant with the elevated VEGFA expression in HRMECs $(p=0.016)$. Cell viability was significantly lower in the $50 \mathrm{mM}, 100 \mathrm{mM}$, and $150 \mathrm{mM}$ groups in RGCs $\left(p_{50 \mathrm{mM}}=0.013, p_{100 \mathrm{mM}}=0.019\right.$, and $\left.p_{150 \mathrm{mM}}=0.002\right)$. Apoptosis was significantly elevated, but the proportion of RGCs with neurite extension was significantly lower in the $50 \mathrm{mM}, 100 \mathrm{mM}$, and $150 \mathrm{mM}$ groups $\left(p_{50 \mathrm{mM}}<0.001, p_{100 \mathrm{mM}}<0.001\right.$, and $\left.p_{150 \mathrm{mM}}<0.001\right)$. Conclusions. We have optimized glucose concentrations to model diabetic retinal endothelial $(25-50 \mathrm{mM})$ or neuronal (50-100 $\mathrm{mM}$ ) dysfunction in vitro, which have a wide range of downstream applications.
\end{abstract}

\section{Introduction}

Diabetic retinopathy (DR) is a leading cause of blindness in the working-age population in both developed and developing countries [1]. DR is the most important neurovascular ocular complications of diabetes mellitus. Identifying new biomarkers for diagnosis and therapeutic targets would greatly benefit patients with DR to prevent vision loss [2].

In vitro models of DR have a crucial role in understanding the pathophysiology of the disease and identifying new therapeutic strategies. The effects of high glucose on retinal cell homeostasis and the identification of potentially protec- tive molecules provide deeper insight from in vitro studies. We have previously shown that apoptosis of neurons and dysfunctions of the retinal blood barrier are the early and key features of DR. Furthermore, neuronal vascular unit dysfunction was identified as the key pathogenesis of DR [1]. Ganglion cells have been recognized as the earliest damaged retinal neurons under hyperglycemia, proved by our previous studies [3].

There is no universally accepted glucose concentration for in vitro studies to simulate human DR. The in vitro model of diabetes is currently and commercially established by treating cells with $5.5 \mathrm{mM}$ to $25 \mathrm{mM}$ concentrations of 
glucose [4-6] and in endothelial cells only. Furthermore, the in vitro glucose concentration is not entirely equivalent to the physiological condition of human beings. The monoglucose concentrations are not optimal for simulation of the blood glucose levels in patients with hyperglycemia, especially for DR. Under the external environment, different cell types have different tolerance to high glucose. Nevertheless, the proper concentrations and the effect of the glucose concentration and osmotic pressure on the biological behavior of HRMEC and neurons have not been fully elucidated [7].

In this study, we investigate the influence of the glucose concentrations gradient on the biological characteristics of HRMEC and RGCs [8]. As the osmotic pressure could be a coeffector in a hyperglycemia pathological condition, we also set up serial control groups of gradient increased osmotic pressure to exclude this effect in human endothelial cells.

\section{Materials and Methods}

2.1. Cell Culture of Human Retinal Microvascular Endothelial and Retinal Ganglion Cells. Primary HRMECs and RGCs were purchased from Shanghai Xuanya Biotechnology Co., Ltd (Shanghai, China). Dulbecco's modified Eagle's medium (DMEM) powder and fetal bovine serum (FBS) were bought from Gibco Life Technologies (New York, NY, USA). HRMECs were cultured in a $5.5 \mathrm{mM}$ glucose DMEM medium containing $10 \%$ FBS in a humidified atmosphere containing $5 \% \mathrm{CO}_{2} / 95 \%$ air at $37^{\circ} \mathrm{C}$. Cells passaged for 4 and 8 times were eased for further experiments.

2.2. Experimental Grouping. Cells were divided in two groups: the control group, which was cultured in DMEM medium supplemented with $5.5 \mathrm{mM}$ glucose, and the highglucose group, cultured in DMEM medium supplemented with G25, G50, G100, and G150 (D-glucose concentrations $25,50,100$, and $150 \mathrm{mmol} / \mathrm{L}$, respectively). The maximum glucose concentration for RGCs is $150 \mathrm{mmol} / \mathrm{L}$. Mannitol was added to the $5.5 \mathrm{mM}$ group to adjust the osmotic pressure to correspond with the same osmotic pressure of G25, G50, G100, and G150, thus forming M25, M50, M100, and M150 (mannitol concentrations 19.5, 44.5, 94.5, and $133.5 \mathrm{mmol} / \mathrm{l}$, respectively). Each experiment was repeated three times.

2.3. Evaluation of the Cutoff and Extreme Value of High Glucose in HRMECs and RGCs. A pilot study was designed to evaluate the cutoff and acute value of high glucose for HRMECs and RGCs. A series glucose concentration was set up as follows: $5.5 \mathrm{mM}, 10 \mathrm{mM}, 15 \mathrm{mM}, 25 \mathrm{mM}, 35 \mathrm{mM}$, $50 \mathrm{mM}, 75 \mathrm{mM}$, and $100 \mathrm{mM}$. Cell proliferative capacity of HRMECs and cell viability of RGCs were assessed via CCK-8 assay before they were treated with different glucose concentrations as previously described [9]. Briefly, cells were seeded in 96-well culture plates $\left(1 \times 10^{4}\right.$ cells/well). After $24 \mathrm{~h}$, the cells were mixed with the control or experimental medium and cultured for an additional 24, 48, and $72 \mathrm{~h}$ (each treatment group has five repeat wells). At each time point, $10 \mu \mathrm{l}$ CCK-8 reagent (Dojindo Molecular Technologies, Inc., Kumamoto, Japan) was added to each well and incubated for another $2 \mathrm{~h}$ at $37^{\circ} \mathrm{C}$. The $\mathrm{OD}$ value of each well was detected at the wavelength of $450 \mathrm{~nm}$ with a microplate reader (SpectraMax 250; GE Healthcare Life Sciences, Chalfont, UK).

\subsection{The Endothelial Cell Transwell Migration and Invasion} Assay. To investigate the migratory response of endothelial cells to hyperglycemia, HRMECs were incubated in a serum-free-conditioned medium at $37^{\circ} \mathrm{C}$ with a humidified atmosphere for $24 \mathrm{~h}$ before the suspension. $100 \mu \mathrm{l}$ of serum-free medium (containing $2 \times 10^{4}$ cells) was added to the upper chambers of a transwell plate with the pore of $8 \mu \mathrm{m}$ ( 24 wells, Corning, NY, USA), while the lower chambers were added with $600 \mu \mathrm{l}$ of complete medium with $20 \%$ FBS. After incubation for $24 \mathrm{~h}, 48 \mathrm{~h}$, and $72 \mathrm{~h}$, migrated cells attached to the other side of the insert were fixed with $90 \%$ ethanol followed stained with $0.1 \%$ crystal violet. Five randomly field $(\times 200)$ photographs were taken under an inverted microscope (Carl Zeiss, Jena, Germany), and the average number of cells was counted. The experiment was repeated three times.

2.5. Detection and Percentage of Apoptotic Cells. Apoptotic cells were detected using a dUTP Nick-End Labeling (TUNEL) kit (\#11684795910, Roche, Mannheim, Germany) and PI/Hoechst staining method. TUNEL assay is designed to identify extensive DNA degradation during the late stages of apoptosis in situ in the apoptotic cells. Briefly, the cells grown on coverslips were fixed with $4 \%$ paraformaldehyde for $1 \mathrm{~h}$ at RT. The cells were incubated with permeabilization solution $(0.1 \%$ Triton $\mathrm{X}-100$ in $0.1 \%$ sodium citrate, freshly prepared) for 2 min on ice after washing with PBS. The cells were then incubated with the TUNEL reaction mixture in a humidified chamber in the dark at $37^{\circ} \mathrm{C}$ for $1 \mathrm{~h}$. After counterstaining with DAPI $(1 \mu \mathrm{g} / \mathrm{ml})$, stained sections were examined by a fluorescence microscope (Carl Zeiss, Jena, Germany). TUNEL-positive nuclei were stained green, and all other nuclei were stained blue.

For PI/Hoechst staining, cells were seeded in 24-well culture plates $\left(2 \times 10^{4}\right.$ cells/well). After each time point of $24 \mathrm{~h}$, $48 \mathrm{~h}$, and $72 \mathrm{~h}$, PI (\#M5109, Abmole Bioscience, USA) and Hoechst (\#M5113, Abmole Bioscience, USA) were added into each well, and the cells were incubated in the dark for 15 min followed by PBS ( 5 minutes each) washing for two times. For quantitative analysis, nine fields were randomly photographed under a 200-fold inverted microscope (Carl Zeiss, Jena, Germany) [10]. Apoptosis index was calculated as the number of positive cells (TUNEL or PI-positive nuclei/the number of DAPI or Hoechst-stained cells).

2.6. Cell Permeability Assay. To evaluate the effects of hyperglycemia on endothelial cell proliferative ability, cell permeability was tested using the BSA-FITC kit $[11,12]$. HRMECs were seeded in the upper Transwell-COL membrane insert (24 wells, Corning Incorporated, NY, USA). After reaching 90\% confluence, the HRMECs were starved for $12 \mathrm{~h}$ in serum-free medium and subsequently replaced with control or experimental medium for $24 \mathrm{~h}$. After $24 \mathrm{~h}$, a tracer solution of FITC-labeled BSA $(250 \mu \mathrm{g} / \mathrm{ml}$; Sigma-Aldrich, 
Germany) was added to the upper insert, and $500 \mu \mathrm{l}$ medium without FITC-BSA was added to the lower insert. After incubation for 2 hours, the collected media were measured using a fluorophotometer (Tecan, Switzerland) at an emission/excitation wavelength of $495 / 520 \mathrm{~nm}$.

2.7. Tube Formation Assay. To evaluate the angiogenic capability under hyperglycemia, $50 \mu \mathrm{l}$ Matrigel (\#356234, BD Biosciences, Oxford, UK) was added to each well of a 96well plate and incubated for $45 \mathrm{~min}$ at $37^{\circ} \mathrm{C}$ in a humidified atmosphere with $5 \% \mathrm{CO}_{2}$ as previously described $[13,14]$. Until Matrigel was polymerized, $5 \times 10^{4}$ cells in $100 \mu \mathrm{l}$ DMEM were seeded in each well. Capillary-like tubes were formed within 9 hours and recorded with a video camera (Carl Zeiss, Jena, Germany). Images of tube morphology were obtained at $\times 100$ magnification and quantified by the ImageJ software (NIH Image, Bethesda, MD) $[13,14]$.

2.8. Detection of VEGFA Protein Concentration. To investigate the pathological mechanisms under hyperglycemia, the supernatant of the different groups was harvested and centrifuged at $4^{\circ} \mathrm{C}$ for $10 \mathrm{~min}$ at $3000 \times \mathrm{g}$ to remove the cell debris, and then it was stored at $-80^{\circ} \mathrm{C}$ for ELISA. After dilution, the concentration of VEGFA in cell supernatants was quantitatively detected using the Human VEGFA ELISA kit (RayBiotech Systems, USA) following the manufacturer's instruction. Data was quantified in comparison to VEGF standards.

2.9. Immunochemistry. RGCs were harvested and seeded in a 24 -well culture plate $\left(3 \times 10^{4}\right.$ cells/well). After incubation for $24 \mathrm{~h}, 48 \mathrm{~h}$, and $72 \mathrm{~h}$, cells were fixed with $4 \%$ paraformaldehyde at RT for $30 \mathrm{~min}$ according to previously described methods [15-17]. After washing with Hank's Balanced Salt Solution (HBSS basic 1x, Gibco Company, USA), cells were permeabilized in $0.3 \%$ Triton (Sigma-Aldrich, Germany) in HBSS for $15 \mathrm{~min}$ at RT. The cells were then blocked with a blocking buffer containing $1 \%$ bovine serum albumin (BSA) and 5\% goat serum in HBSS for 60 minutes after washing with HBSS. After incubation with the primary antibodies, rabbit anti-beta III tubulin $(1: 1000$,Cat\#ab18207,Abcam,Cambridge, MA), which was specific for neurofilament heavy chains [18], and mouse anti-Brn3a ( $1: 25$, Cat\#sc-8429, Santa, USA), which was specific expression in RGCs nucleus $[17,19]$ for overnight at $4^{\circ} \mathrm{C}$, the cells were washed three times and incubated with secondary antibodies (goat anti-mouse and goat anti-rabbit) $(1: 500$, Cat \#ab150077, Cat \#ab150116, Abcam, Cambridge, MA) at RT for 2 hours with light-shielded and counterstained with DAPI. Five fields were randomly photographed under a 200-fold inverted microscope (Carl Zeiss, Jena, Germany). The number of cells which had neurite lengths equal to or greater than three times the cell body diameter was calculated by ImageJ.

2.10. Statistical Analysis. Statistical analysis was performed using the SPSS software version 20.0 (SPSS, Inc., Chicago, IL, USA). Data distribution was assessed by the OneSample Kolmogorov-Smirnov test. Data were expressed as means \pm SD or median (interquartile range). Variance
(ANOVA) analysis for continuous variables and chi-square test for noncontinuous variables were applied. The Bonferroni correction was used for multiple-comparison correction. A $p$ value less than 0.05 is considered significant.

If the above analysis confirmed any significant difference, a comparison between two groups was then conducted by independent Student's $t$-test for continuous variables and post hoc test to compare the difference between groups for noncontinuous variables. $p$ values $<0.05$ was considered statistically significant.

\section{Results}

3.1. $25 \mathrm{mM}$ and $50 \mathrm{mM}$ May Be Taken as the Cutoff Value of Hyperglycemia for Retinal Vascular Endothelial Cells. Significant difference was found in the optical density (OD) value in the different glucose concentration groups at $24 \mathrm{~h}, 48 \mathrm{~h}$, and $72 \mathrm{~h}$ by the CCK- 8 assay $\left(F_{24 \mathrm{~h}}=41.789, p<0.001\right.$; $F_{48 \mathrm{~h}}=181.054, p<0.001 ;$ and $\left.F_{72 \mathrm{~h}}=51.189, p<0.001\right)$. There was significant difference in the $\mathrm{OD}$ value in the groups of $25 \mathrm{mM}, 50 \mathrm{mM}$, and $100 \mathrm{mM}$ compared to the $5.5 \mathrm{mM}$ group $(p<0.01)$, but no difference was found in the $10 \mathrm{mM}$ and $15 \mathrm{mM}$ groups compared to the $5.5 \mathrm{mM}$ control group $(p>0.05)$. The glucose concentration of $25 \mathrm{mM}$ can be regarded as the cutoff value of DR. When the glucose concentration is greater than $50 \mathrm{mM}(50 \mathrm{mM}, 75 \mathrm{mM}$, and $100 \mathrm{mM}$ ), the proliferation capacity of HREMC was obviously inhibited.

We further investigate the CCK- 8 assay and AI in the groups of $5.5 \mathrm{mM}, 25 \mathrm{mM}, 50 \mathrm{mM}$, and $100 \mathrm{mM}$ to explore the extreme value of in vitro model of DR. We found that the proliferative capacity in the $50 \mathrm{mM}$ is significantly lower compared to the $5.5 \mathrm{mM}$ group ( $24 \mathrm{~h}: 0.91 \pm 0.03$ vs. 0.96 $\pm 0.45, p<0.001 ; 48 \mathrm{~h}: 1.27 \pm 0.05$ vs. $1.36 \pm 0.05, p<$ 0.001 ; and $72 \mathrm{~h}: 1.48 \pm 0.06$ vs. $1.58 \pm 0.03, p=0.001$ ); furthermore, cell proliferation capacity was obviously inhibited in the $100 \mathrm{mM}$ group ( $24 \mathrm{~h}: 0.87 \pm 0.02$ vs. $0.96 \pm 0.45, p<$ $0.001 ; 48 \mathrm{~h}: 1.18 \pm 0.02$ vs. $1.36 \pm 0.05, p<0.001$; and $72 \mathrm{~h}$ : $1.23 \pm 0.01$ vs. $1.58 \pm 0.03, p<0.001)$, which was not suitable for further study (Figure 1). In the TUNEL assay, the AI is significantly increased in the $25 \mathrm{mM}$ glucose-treated group compared with the $5.5 \mathrm{mM}$ group $(19.89 \% \pm 5.82 \%$ vs. $8.87 \% \pm 3.09 \%, p=0.024)$, and the increasing linear trend was found. In summary, the cell permeability, migration ability and AI of HRMEC showed an increasing trend, from $25 \mathrm{mM}$ to $50 \mathrm{mM}$, while capacities were inhibited when glucose concentration increased further. $50 \mathrm{mM}$ may be equal to the acute clinical value of diabetes and the extreme limit value in an in vitro study.

3.2. Cells Treated with $25 \mathrm{mM}$ Have Higher Proliferative Capacity Compared to those Treated with $5.5 \mathrm{mM}$. The CCK-8 assay showed significant difference in OD values of each group after $24 \mathrm{~h}$ of culture $(F=25.567, p<0.001)$. Compared to the control group, the OD in the G25 group was significantly higher ( $1.01 \pm 0.05$ vs. $0.96 \pm 0.45$ (control), $p<0.001$ ), while it was significantly lower in the G50 and G100 groups $\left(0.91 \pm 0.03\right.$ vs. $0.96 \pm 0.45, p_{\mathrm{G} 50}<0.001$; $0.87 \pm 0.02$ vs. $0.96 \pm 0.45, p_{\mathrm{G} 100}<0.001$, respectively); in 


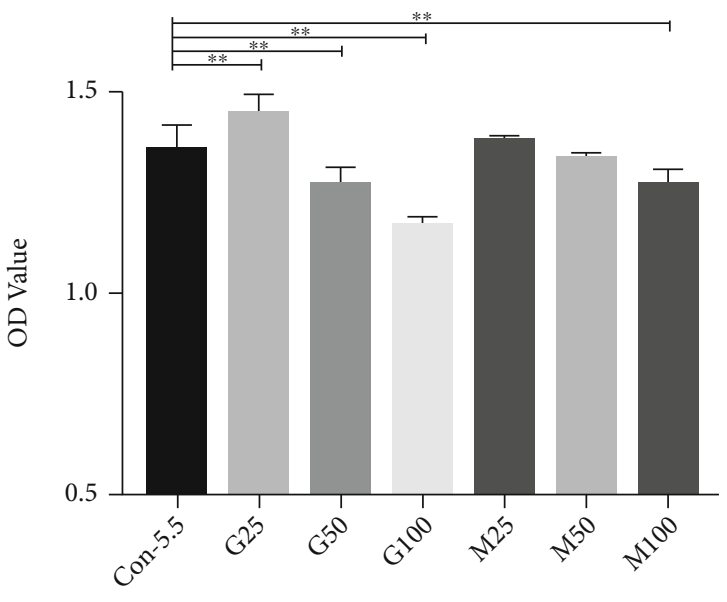

Figure 1: Cell proliferative ability of HRMECs using the CCK-8 assay. At $48 \mathrm{~h}$ after culturing, compared to the control group, increased cell proliferation at 48 was found in the G25 group, while the OD value was significantly lower in the G50 and G100 groups. No significant difference was observed between the hypertonic group and the control group. Con-5.5, G25-G100: concentration of glucose $(5.5,25,50$, and $100 \mathrm{mmol} / \mathrm{l}$, respectively); M25-M100: concentration of M-mannitol (19.5, 44.5, and $94.5 \mathrm{mmol} / \mathrm{l}$, respectively). CCK-8: Cell Counting Kit-8 assay. HRMEC: human retinal endothelial cell. OD value: optical density value. ${ }^{*} p<0.05 ;{ }^{* *} p<0.01$.

addition, no significant difference was observed between the hypertonic group and the control group.

Similar results were observed after $48 \mathrm{~h}$ of culturing $(F=79.037, p<0.001)$. Compared to the control group, the $\mathrm{OD}$ in the G25 group was significantly higher $(1.45 \pm 0.04$ vs. $1.36 \pm 0.05, p<0.001)$, while it was significantly lower in the G50 and G100 groups ( $1.27 \pm 0.05$ vs. $1.36 \pm 0.05, p<0.001 ; 1.18 \pm 0.02$ vs. $1.36 \pm 0.05, p<0.001$, respectively). In addition, the M100 group was lower than the control group, and the difference was statistically significant $(1.18 \pm 0.02$ vs. $1.36 \pm 0.05, p<0.001$, respectively) (Figure 1).

After $72 \mathrm{~h}$ culturing, the overall difference of OD value between the groups was statistically significant $(F=61.144$, $p<0.001)$. Compared to the control group, the OD in the G25 group was significantly higher $(1.65 \pm 0.12$ vs. $1.58 \pm$ $0.03, p=0.006$ ), while it was significantly lower in the G50 and G100 groups ( $1.48 \pm 0.06$ vs. $1.58 \pm 0.03, p<0.001$; $1.23 \pm 0.01$ vs. $1.58 \pm 0.03, p<0.001$, respectively). Compared with the control group, the M50 and M100 groups in the hypertonic group were significantly reduced $(1.41 \pm 0.02$ vs. $1.58 \pm 0.03, p<0.001 ; 1.39 \pm 0.07$ vs. 1.58 $\pm 0.03, p<0.001$, respectively) (Figure 1 ). The results indicated that the better time point for studying HRMECs under higher glucose is at $48 \mathrm{~h}$ after culturing.

\subsection{HRMECs Treated with $25 \mathrm{mM}$ or $50 \mathrm{mM}$ Have Higher} Migration Capacity Compared to Those Treated with $5.5 \mathrm{mM}$ (Transwell). Significant difference of the migration cells was found between the different glucose concentration groups at $48 \mathrm{~h}$ by transwell assay $(F=4.412, p=0.008)$.
The migration ability in HRMECs using transwell assay revealed that there was a significantly increased number of migration cells in the $25 \mathrm{mM}(238 \pm 29$ vs. $200 \pm 42, p=$ $0.026), 50 \mathrm{mM}(230 \pm 16$ vs. $200 \pm 42, p=0.021)$, and $100 \mathrm{mM}$ groups $(228 \pm 18$ vs. $200 \pm 42, p=0.031)$ in comparison with the control $5.5 \mathrm{mM}$ group at $48 \mathrm{~h}$ (Figure 2).

After 24, 48, and $72 \mathrm{~h}$, the cell migration rate of the control group was $35.84 \% \pm 8.19 \%, 49.00 \% \pm 11.43 \%$, and $59.31 \% \pm 13.29 \%$, respectively. Compared to the control group, at $24 \mathrm{~h}$ of culture, higher cell migration rate was observed in the G25 and G50 groups $(45.79 \% \pm 5.28 \%$ vs. $35.84 \% \pm 8.19 \%, p<0.001 ; 46.13 \pm 5.53 \%$ vs. $35.84 \% \pm 8.19$ $\%, p<0.001)$, while it was lower in the G100 and M100 groups $(25.54 \% \pm 3.38 \%$ vs. $35.84 \% \pm 8.19 \%, \quad p<0.001$; $20.39 \% \pm 7.62 \%$ vs. $35.84 \% \pm 8.19 \%, p<0.001)$. A similar effect was observed at 48 and $72 \mathrm{~h}$ post culture (all $p<0.05$ ).

3.4. Apoptosis Indexes in Cells Treated with $25 \mathrm{mM}$ or $50 \mathrm{mM}$ Compared to Those Treated with $5.5 \mathrm{mM}$ in HRMEC. $\mathrm{PI} /$ Hoechst staining and ImageJ were used to quantify the live and dead cells. We found that the apoptosis indexes of $5.5 \mathrm{mM}$ groups, G25, G50, G100, M25, M50, and M100 groups were $7.71 \% \pm 0.80 \%, 10.67 \% \pm 2.06 \%, 11.06 \% \pm 0.47 \%, 5.04 \% \pm$ $0.40 \%, 8.07 \% \pm 0.60 \%, 8.93 \% \pm 0.56 \%$, and $5.98 \% \pm 0.33 \%$, respectively, and the overall difference between the two groups was statistically significant $(F=51.101, p<0.001)$ after $24 \mathrm{~h}$ of cell culturing. The apoptosis indexes of the G25 and G50 groups were significantly higher compared to the control group $(10.67 \% \pm 2.06 \%$ vs. $7.71 \% \pm 0.80 \%, p<0.001 ; 11.06$ $\% \pm 0.47 \%$ vs. $7.71 \% \pm 0.80 \%, p<0.001)$.

At $48 \mathrm{~h}$, the cell apoptosis indexes of $5.5 \mathrm{mM}$ groups, G25, G50, G100, M25, M50, and M100 groups were $11.16 \% \pm$ $0.84 \%, \quad 20.84 \% \pm 0.44 \%, \quad 18.50 \% \pm 0.88 \%, \quad 11.19 \% \pm 0.60 \%$, $11.87 \% \pm 0.40 \%, \quad 15.55 \% \pm 0.81 \%$, and $14.15 \% \pm 0.43 \%$, respectively. The overall difference between the groups was statistically significant $(F=297.784, p<0.001)$. The apoptosis indexes of G25, G50, and M50 groups were significantly higher compared to the control group, and the difference was statistically significant $(20.84 \% \pm 0.44 \%$ vs. $11.16 \% \pm$ $0.84 \%, p<0.001 ; 18.50 \% \pm 0.88 \%$ vs. $11.16 \% \pm 0.84 \%, p<$ 0.001 ; and $15.55 \% \pm 0.81 \%$ vs. $11.16 \% \pm 0.84 \%, p<0.001)$.

At $72 \mathrm{~h}$, the AI of $5.5 \mathrm{mM}, \mathrm{G} 25, \mathrm{G} 50, \mathrm{G} 100, \mathrm{M} 25, \mathrm{M} 50$, and M100 groups was $16.06 \% \pm 0.42 \%, 27.02 \% \pm 0.96$, $25.56 \% \pm 0.96 \%, 20.15 \% \pm 0.64 \%, 17.97 \% \pm 1.17 \%, 20.86 \%$ $\pm 0.68 \%$, and $21.72 \% \pm 0.81 \%$, respectively. The overall difference between the groups was statistically significant $(F=194.267, p<0.001)$. The apoptosis indexes of the G25, G50, M25, M50, and M100 groups were significantly higher than that in the control group, and the difference was statistically significant $(p<0.001)$.

The TUNEL analysis further confirmed the PI/Hoechst result. The AI of the HRMECs in the $25 \mathrm{mM}, 50 \mathrm{mM}$, and $100 \mathrm{mM}$ is significantly higher than that in the control group $\left(p_{25 \mathrm{mM}}=0.024, p_{50 \mathrm{mM}}=0.001\right.$, and $\left.p_{100 \mathrm{mM}}<0.001\right)$ at $48 \mathrm{~h}$ (Figure 3).

3.5. HRMEC Treated with Hyperglycemia Groups Poses Higher Permeability Compared to Those Treated with $5.5 \mathrm{mM}$. After $24 \mathrm{~h}$ of cell culturing, the cell permeability of 


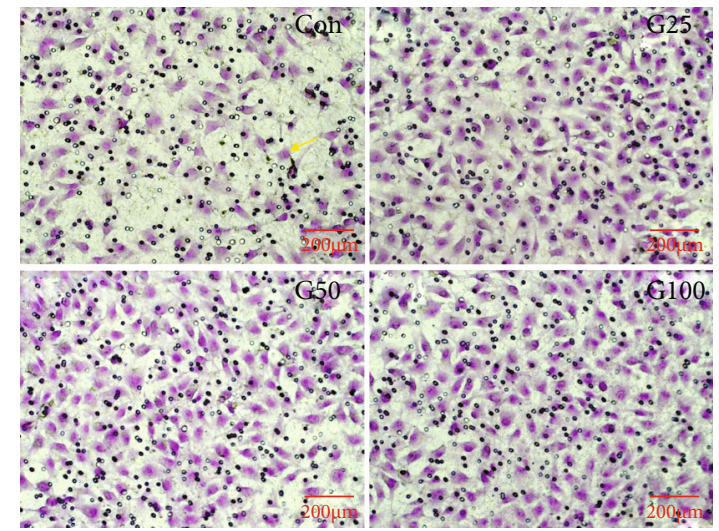

(a)

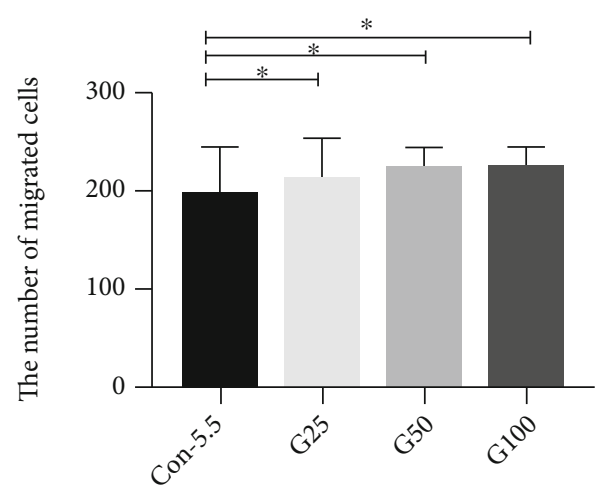

(b)

FIGURE 2: Cell migration ability detected by Transwell assay. (a) Representative images of migrated HRMECs treated with $5.5 \mathrm{mM}, 25 \mathrm{mM}$, $50 \mathrm{mM}$, and $100 \mathrm{mM}$ glucose, respectively, at $48 \mathrm{~h}$. HRMEC cells were stained with $0.1 \%$ crystal violet (yellow, arrows). (b) The number of migrated HRMEC was significant higher in the $25 \mathrm{mM}(238 \pm 29$ vs. $200 \pm 42, p=0.026), 50 \mathrm{mM}(230 \pm 16$ vs. $200 \pm 42, p=0.021)$, and $100 \mathrm{mM}(228 \pm 18$ vs. $200 \pm 42, p=0.031)$ groups in comparison with the $5.5 \mathrm{mM}$ groups. Scale bar: $200 \mu \mathrm{m}$ (a). HRMEC: human retinal vascular endothelial cells; Con: control group (5.5 mmol/l); G25: $25 \mathrm{mmol} / \mathrm{l} ; \mathrm{G} 50: 50 \mathrm{mmol} / \mathrm{l} ; \mathrm{G} 100: 100 \mathrm{mmol} / \mathrm{l} .{ }^{*} p<0.05$.
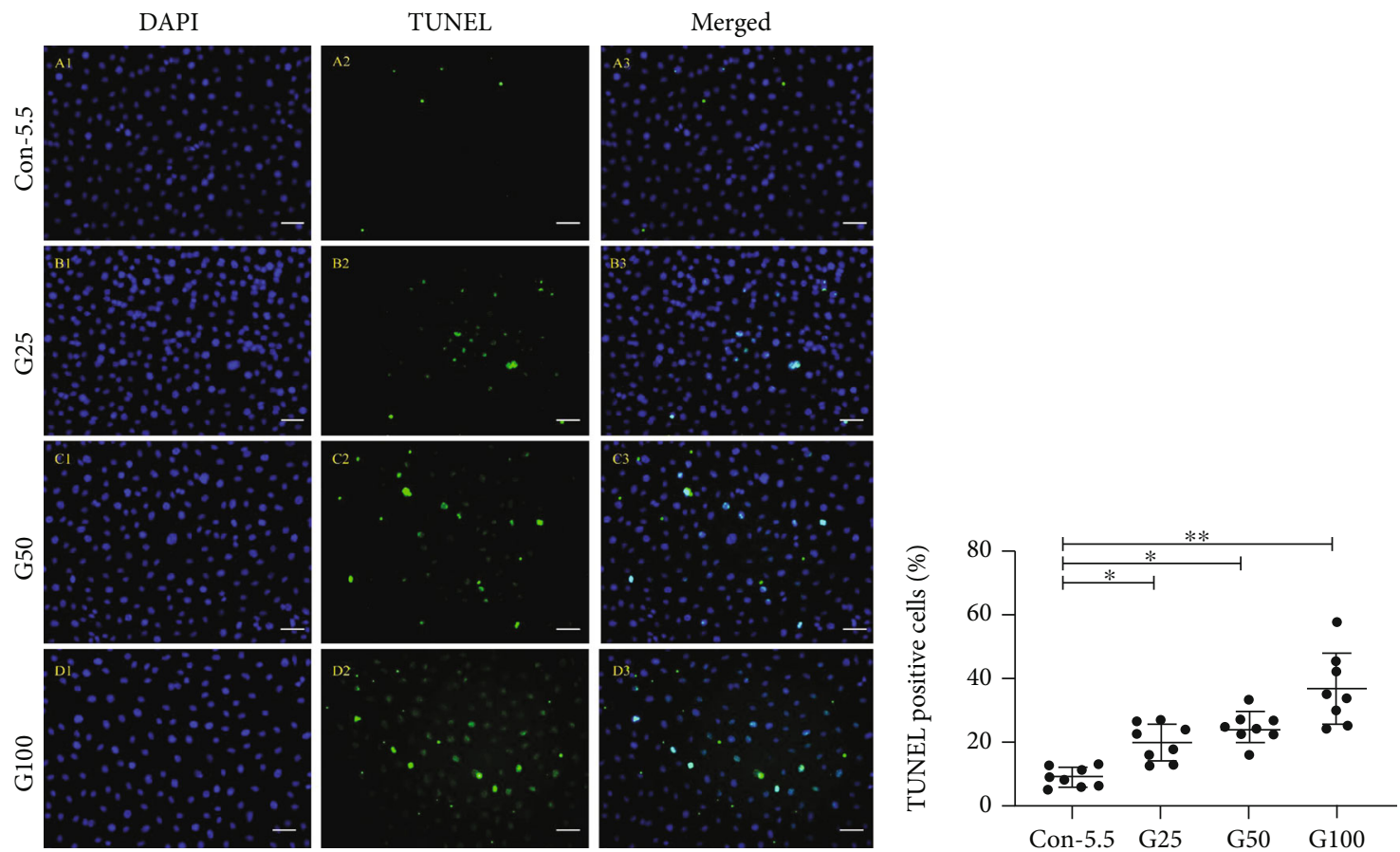

FIGURE 3: Representative fluorescence images and quantification of TUNEL-positive HRMECs. TUNEL staining (green, A2-D2), DAPI staining (blue, A1-D1), and merged image of HRMECs with different treatments. Merged images are presented as A3-D3. Con-5.5, G25G100: concentration of glucose $(5.5,25,50$, and $100 \mathrm{mmol} / \mathrm{l}$, respectively). HRMECs: human retinal microvascular endothelial cells. Scale bar: $200 \mu \mathrm{m} .{ }^{*} p<0.05{ }^{* *} p<0.01$.

$5.5 \mathrm{mM}$, G25, G50, G100, M25, M50, and M100 groups was $8.12 \% \pm 0.56 \%, \quad 8.42 \% \pm 0.23 \%, \quad 8.82 \% \pm 0.26 \%, \quad 8.83 \% \pm$ $0.25 \%, 8.39 \% \pm 0.24 \%, 8.47 \% \pm 0.25 \%$, and $8.52 \% \pm 0.27 \%$, respectively. Cell permeability slightly increased with the increase of glucose concentration. In addition, no significant effect on cell permeability was observed in the mannitolcontrol groups.

3.6. The Angiogenic Ability of HRMEC Is Higher in the $25 \mathrm{mM}$ and $50 \mathrm{mM}$ Groups Compared to the $5.5 \mathrm{mM}$ Group.
Angiogenesis was evaluated by a Matrigel-based tube formation assay and protein expression analysis of VEGFA in different groups. The number of tubes at 9 hours increased with the concentration of glucose $(5.5 \mathrm{mM}$ : $23.5 \pm 9.87$, $25 \mathrm{mM}: 34.33 \pm 1.51$; and $50 \mathrm{mM}: 40 \pm 5.02$ ), respectively $(F=10.124, p=0.002)$, showing a statistical significance among the groups. The number of branch points was also significantly increased in the higher glucose groups (5.5 mM: $9 \pm 3.16,25 \mathrm{mM}: 21.67 \pm 0.52$, and $50 \mathrm{mM}: 26.67$ \pm 1.97 , respectively, $F=105.613, p<0.001)$. The area of 

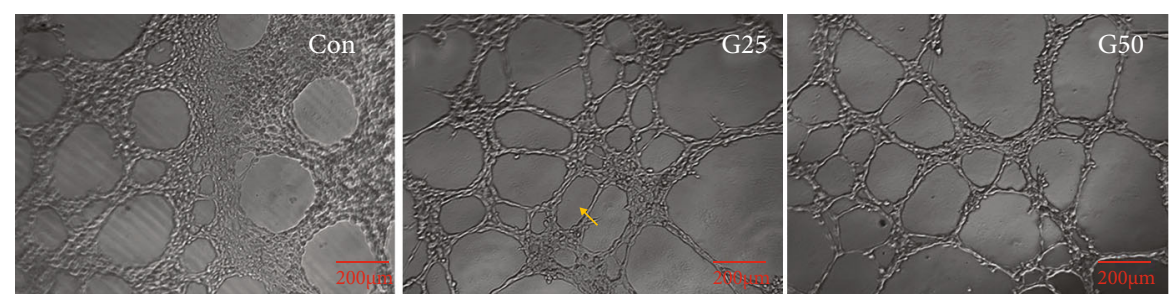

(a)
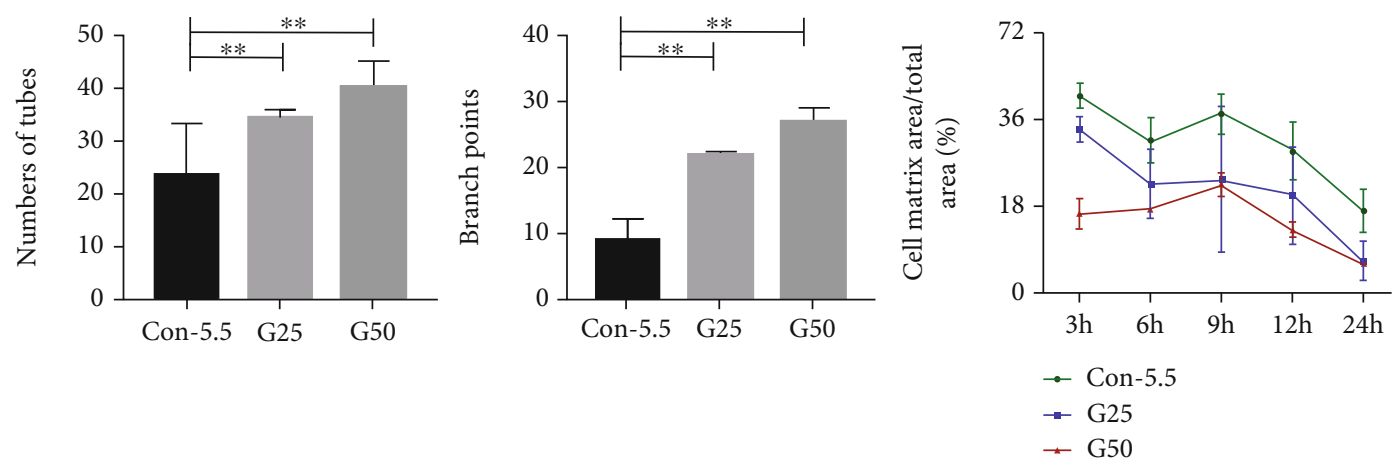

(b)

FIgURE 4: A Matrigel-based tube formation assay to assess the vasogenic activity of HRMEC. G25/G50 showed a stimulatory effect on angiogenic tube formation in the Matrigel assay. (a) HREMCs were cultured on Matrigel, and the cumulative numbers of circle-like structures (yellow arrow) and branch points were measured after $9 \mathrm{~h}$. (b) The vasculogenic capacity was quantified in cells treated with different groups. Con-5.5, G25, and G50: concentration of glucose (5.5, 25, and $50 \mathrm{mmol} / \mathrm{l}$, respectively). Tube formation assay was examined under an inverted fluorescence microscope with a $\times 10$ objective. HRMEC: human retinal vascular endothelial cells. Scale bar: $200 \mu \mathrm{m}(\mathrm{a}) .{ }^{*} p<0.05 ;{ }^{* *} p<0.01$.

the extracellular (tube metrics area) in the G25 and G50 groups were significantly less than that in the $5.5 \mathrm{mM}$ group $\left(p_{\mathrm{G} 25}=0.013, p_{\mathrm{G} 50}=0.024\right)$ (Figure 4$)$.

ELISA was used to detect VEGFA secretion from HRMECs into the medium. The results showed that the amount of VEGFA secreted increased with increasing glucose concentrations $(F=9.000, p=0.016)$.

3.7. The Biological Behavior of RGCs under Hyperglycemia Condition. The cell variability of RGCs was detected by the CCK-8 assay. The OD value between the $5.5 \mathrm{mM}, \mathrm{G} 25$, G50, G100, G150, M25, M50, M100, and M150 groups was statistically significant $(F=8.041, p<0.001)$ at $48 \mathrm{~h}$. The OD value was significantly higher in the $25 \mathrm{mM}$ $(1.871 \pm 0.218$ vs. $1.718 \pm 0.100, p=0.023)$, while it was lower in the $50 \mathrm{mM}(1.607 \pm 0.128$ vs. $1.718 \pm 0.100, p=$ $0.013), 100 \mathrm{mM}(1.562 \pm 0.215$ vs. $1.718 \pm 0.100, p=0.019)$, and $150 \mathrm{mM}(1.535 \pm 0.185$ vs. $1.718 \pm 0.100, p=0.002)$ in comparison with the control $5.5 \mathrm{mM}$ at $48 \mathrm{~h}$. Compared with the control group, the M25, M50, and M100 groups were not significantly reduced $\left(p_{\mathrm{M} 25}=0.240, p_{\mathrm{M} 50}=0.416\right.$, and $p_{\mathrm{M} 100}$ $=0.163)$ at $48 \mathrm{~h}$. The same declined trend of OD value was also found at $24 \mathrm{~h}$ and $72 \mathrm{~h}$ (Figure 5).

RGCs are the earliest affected retinal neurons in the retina. The long axons of RGCs play an important role in transmitting visual information along with photoreceptors, horizontal cells, amacrine cells, and bipolar cells, from the retina to the brain $[20,21]$. To further evaluate the effects of hyperglycemia, the axons, which are the sole retinal neu- ron projections, connect the RGC cell body and brain. It is defined as the longest neurite extending from the RGC cell body [22]. RGCs were labeled by neurons and RGCspecific markers TUJ1 and BRN3A, respectively, followed by the ImageJ quantitative analysis. The proportion of RGCs with neurite extensions in the $5.5 \mathrm{mM}$, G25, G50, G100, G150, M25, M50, M100, and M150 groups was statistically significant $(F=49.655, p<0.001)$ at $48 \mathrm{~h}$. Immunofluorescence staining revealed that the proportion of RGCs with neurite extensions was significantly lower in the $25 \mathrm{mM}$ $(33 \pm 13$ vs. $49 \pm 5, p=0.007), 50 \mathrm{mM}(21 \pm 7$ vs. $49 \pm 5, p<$ $0.001), 100 \mathrm{mM}$ ( $20 \pm 7$ vs. $49 \pm 5, p<0.001)$, and $150 \mathrm{mM}$ (17 \pm 6 vs. $49 \pm 5, p<0.001)$ groups in comparison with that in the control group $(5.5 \mathrm{mM})$ at $48 \mathrm{~h}$. Compared with the control group, the M25, M50, M100, and M150 groups in the hypertonic group were not significantly different $\left(p_{\mathrm{M} 25}=0.691, p_{\mathrm{M} 50}=0.297, p_{\mathrm{M} 100}=0.716\right.$, and $p_{\mathrm{M} 150}=$ $0.356)$ (Table 1). Apoptosis in RGCs was detected and quantified by the PI/Hoechst fluorescent staining and TUNEL assay, followed by the ImageJ analysis. AI was found statistical significance in the different glucose concentration groups at $24 \mathrm{~h}, 48 \mathrm{~h}$, and $72 \mathrm{~h}$ detected by the PI/Hoechst staining $\left(F_{24 \mathrm{~h}}=27.648, p=0.001 ; F_{48 \mathrm{~h}}=11.863, p<0.001 ;\right.$ and $F_{72 \mathrm{~h}}$ $=9.880, p<0.001)$. Compared to the control group, the AI of the G50, G100, and G150 groups was significantly higher after $24 \mathrm{~h}$ of cell culturing $\left(p_{\mathrm{G} 50}=0.015, p_{\mathrm{G} 100}=0.003\right.$, and $\left.p_{\mathrm{G} 150}=0.001\right)$. AI in the G25, G100, and G150 groups was significantly higher than that in the control group at $48 \mathrm{~h}$ $\left(p_{\mathrm{G} 25}=0.006, p_{\mathrm{G} 100}=0.006\right.$, and $\left.p_{\mathrm{G} 150}=0.002\right)$. The AI of 


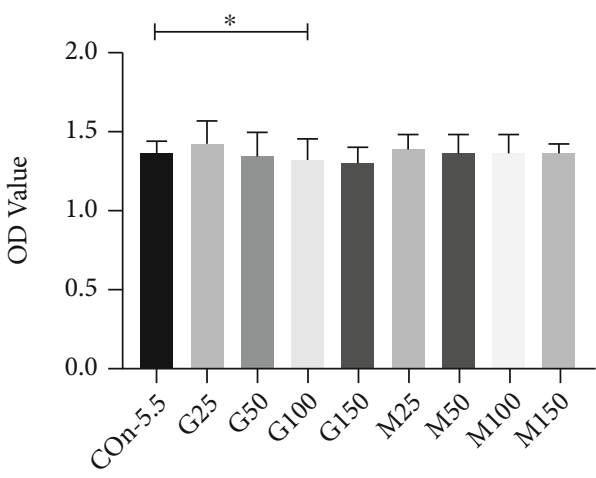

(a)

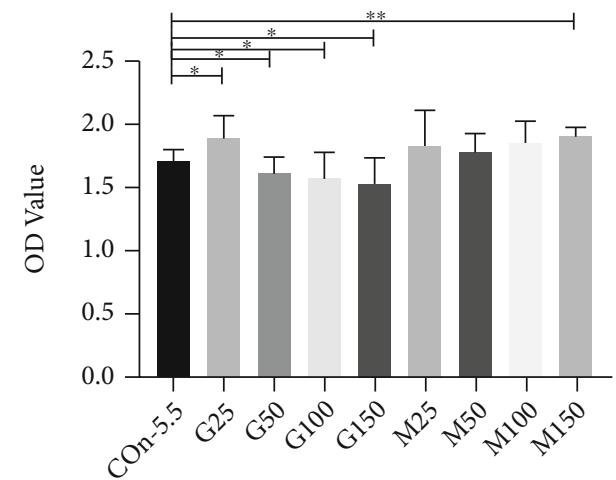

(b)

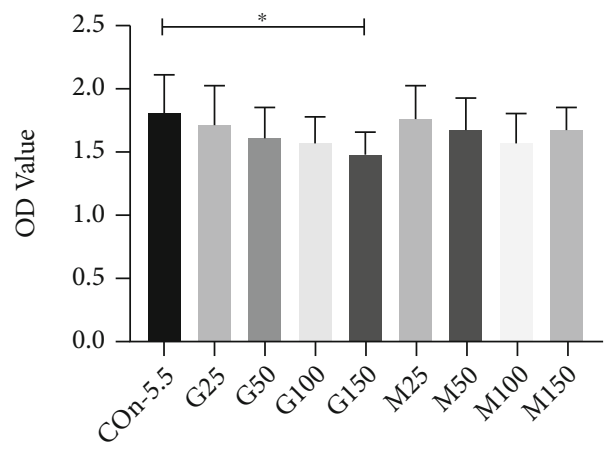

(c)

FIGURE 5: Cell viability of RCGs by the CCK-8 assay. Compared to the control group, the OD value was significantly lower in the G50, G100, and G150 at $48 \mathrm{~h}$. (a-c) Cell proliferation ability in RGCs treated with different groups at 24, 48, and 72h. Con-5.5, G25-G150: concentration of glucose $(5.5,25,50,100$, and $150 \mathrm{mmol} / \mathrm{l}$, respectively); M25-M150: concentration of M-mannitol (19.5, 44.5, 94.5, and $133.5 \mathrm{mmol} / \mathrm{l}$, respectively). ${ }^{*} p<0.05$; ${ }^{* *} p<0.01$. RGCs: retinal ganglion cells CCK-8: Cell Counting Kit-8 assay OD value: optical density value.

TAble 1: Neurite extensions in RGCs detected by immunofluorescence staining at $48 \mathrm{~h}$.

\begin{tabular}{lcc}
\hline Groups & $\begin{array}{c}\text { The proportion of RGCs } \\
\text { with neurite extensions (\%) }\end{array}$ & $p$ value \\
\hline Con & $49 \pm 5$ & - \\
G25 & $33 \pm 13$ & $0.007^{a} *$ \\
G50 & $21 \pm 7$ & $<0.001^{a *}$ \\
G100 & $20 \pm 7$ & $<0.001^{a} *$ \\
G150 & $17 \pm 6$ & $<0.001^{a}$ \\
M25 & $51(42-55)$ & $0.691^{\mathrm{b}}$ \\
M50 & $43 \pm 15$ & $0.297^{\mathrm{b}}$ \\
M100 & $50 \pm 13$ & $0.716^{\mathrm{a}}$ \\
M150 & $46 \pm 9$ & $0.356^{\mathrm{a}}$ \\
\hline
\end{tabular}

*Statistically significant: ${ }^{*} p<0.05$. According to the type of data and the data distribution, ${ }^{a}$ independent-sample $t$-test and the ${ }^{\mathrm{b}}$ Mann-Whitney $U$ test were applied. Con-5.5, G25-G150: concentration of glucose (5.5, 25, 50,100 , and $150 \mathrm{mmol} / \mathrm{l}$, respectively); M25-M150: concentration of Mmannitol (19.5, 44.5, 94.5, and $133.5 \mathrm{mmol} / \mathrm{l}$, respectively). RGCs: retinal ganglion cells.

the G50, G100, and G150 groups was significantly higher than that of the control group at $72 \mathrm{~h}\left(p_{\mathrm{G} 50}=0.003, p_{\mathrm{G} 100}\right.$ $=0.016$, and $\left.p_{\mathrm{G} 150}=0.001\right)$. In addition, the AI of hyper- tonic groups was not significantly higher than that in the $5.5 \mathrm{mM}$ group at $24 \mathrm{~h}, 48 \mathrm{~h}$, and $72 \mathrm{~h}$ (all $p>0.05$ ) (Table 2).

TUNEL assay further confirmed the above results. The $\mathrm{AI}$ of the RGCs in the $50 \mathrm{mM}, 100 \mathrm{mM}$, and $150 \mathrm{mM}$ is significantly higher than that in the control group $\left(p_{50 \mathrm{mM}}<0.001, p_{100 \mathrm{mM}}<0.001\right.$, and $\left.p_{150 \mathrm{mM}}<0.001\right)$ at $48 \mathrm{~h}$ (Table 3).

\section{Discussion}

In this study, we have optimized glucose concentrations to model diabetic retinal endothelial $(25-50 \mathrm{mM})$ or neuronal (50-150 $\mathrm{mM})$ dysfunction in vitro, which have a wide range of downstream applications.

In vitro studies have been colloquially named "test-tube" experiments, providing a convenient, time- or cost-consuming, specific, and more detailed analysis which cannot be done within the whole organism. The advantages of in vitro study are simplicity [22-24], species specificity [25], convenience and automation [26]. In vitro studies are essential to explore the pathophysiology of retinal damage by hyperglycemia $[27,28]$. Immortalized cell lines and primary isolated retinal endothelial and ganglion cells are currently the most widely used in vitro models for exploring the pathogenesis of DR, a neuronal vascular disorder [8]. 
TABle 2: Apoptotic index in RGCs at $24 \mathrm{~h}, 48 \mathrm{~h}$, and $72 \mathrm{~h}$.

\begin{tabular}{|c|c|c|c|c|c|c|}
\hline Groups & $\begin{array}{c}24 \mathrm{~h} \\
\text { Apoptotic index }\end{array}$ & $p$ value & $\begin{array}{c}48 \mathrm{~h} \\
\text { Apoptotic index }\end{array}$ & $p$ value & $\begin{array}{c}72 \mathrm{~h} \\
\text { Apoptotic index }\end{array}$ & $p$ value \\
\hline Con & $0.042(0.028-0.047)$ & - & $0.013 \pm 0.007$ & & $0.091 \pm 0.031$ & - \\
\hline $\mathrm{G} 25$ & $0.069(0.031-0.112)$ & $0.171^{b}$ & $0.024 \pm 0.007$ & $0.006^{\mathrm{a}}$ & $0.132 \pm 0.083$ & $0.182^{\mathrm{a}}$ \\
\hline G50 & $0.108(0.071-0.144)$ & $0.015^{\mathrm{b}}$ & $0.018 \pm 0.009$ & $0.284^{\mathrm{a}}$ & $0.225 \pm 0.095$ & $0.003^{a *}$ \\
\hline G100 & $0.120(0.061-0.256)$ & $0.003^{\mathrm{b}}$ & $0.025 \pm 0.008$ & $0.006^{\mathrm{a}}$ & $0.181 \pm 0.088$ & $0.016^{a *}$ \\
\hline G150 & $0.148(0.079-0.184)$ & $0.001^{b}$ & $0.055 \pm 0.027$ & $0.002^{\mathrm{a}}$ & $0.291 \pm 0.124$ & $0.001^{a *}$ \\
\hline M25 & $0.049(0.025-0.082)$ & $0.691^{b}$ & $0.016 \pm 0.003$ & $0.329^{\mathrm{a}}$ & $0.089 \pm 0.024$ & $0.893^{\mathrm{a}}$ \\
\hline M50 & $0.036(0.024-0.059)$ & $0.691^{b}$ & $0.017 \pm 0.004$ & $0.221^{\mathrm{a}}$ & $0.089 \pm 0.030$ & $0.856^{\mathrm{a}}$ \\
\hline M100 & $0.050(0.030-0.065)$ & $0.354^{\mathrm{b}}$ & $0.019 \pm 0.004$ & $0.054^{\mathrm{a}}$ & $0.097 \pm 0.040$ & $0.733^{\mathrm{a}}$ \\
\hline M150 & $0.056(0.030-0.082)$ & $0.270^{\mathrm{b}}$ & $0.016 \pm 0.008$ & $0.455^{\mathrm{a}}$ & $0.093 \pm 0.031$ & $0.918^{\mathrm{a}}$ \\
\hline
\end{tabular}

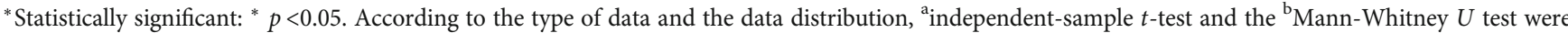
applied. Con-5.5, G25-G150: concentration of glucose (5.5, 25, 50, 100, and $150 \mathrm{mmol} / \mathrm{l}$, respectively); M25-M150: concentration of M-mannitol (19.5, 44.5, 94.5 , and $133.5 \mathrm{mmol} / \mathrm{l}$, respectively).

TABle 3: TUNEL-positive cells in RGCs using TUNEL staining at $48 \mathrm{~h}$.

\begin{tabular}{lcc}
\hline Groups & TUNEL-positive cells (\%) & $p$ value \\
\hline Con & $14.97 \pm 7.48$ & - \\
G25 & $27.31 \pm 2.41$ & 0.364 \\
G50 & $44.88 \pm 7.31$ & $<0.001^{*}$ \\
G100 & $52.20 \pm 2.86$ & $<0.001^{*}$ \\
G150 & $84.37 \pm 2.43$ & $0.001^{*}$ \\
\hline
\end{tabular}

* $p$ value: the difference of the high-glucose groups $(25 \mathrm{mM}, 50 \mathrm{mM}$, $100 \mathrm{mM}$, and $150 \mathrm{mM})$ and the control group $(5.5 \mathrm{mM})$ was analyzed with one-way analysis of variance.

Currently, the commercially available in vitro model of DR in different cell types is $5.5 \mathrm{mM}$ (as the normal control) and $25 \mathrm{mM}$ (as the higher glucose) for HRMEC and $35 \mathrm{mM}$ for RGCs, respectively [29-31]. However, there is no evidence to prove that $25 \mathrm{mM}$ or $30 \mathrm{mM}-35 \mathrm{mM}$ glucose in vitro model is simulation to the physiological conditions (hyperglycemia) of the human body, and $25 \mathrm{mM}$ should not be considered the upper limit of in vitro research. In this study, we found that concentrations of $25 \mathrm{mM}$ to $50 \mathrm{mM}$ glucose could induce the proliferation of HRMEC, promote cell migration capacity, and improve angiogenic ability (tube formation), promoting cell apoptosis (from $25 \mathrm{mM}$ to $100 \mathrm{mM}$ ). All of the above results indicate that $25 \mathrm{mM}$ is a cutoff value, and $25-50 \mathrm{mM}$ is the proper concentration to stimulate diabetic microvasculopathy. This concentration range also can be used to study retinal neovascularization in proliferative retinopathy. Furthermore, under the hyperglycemia pathological condition, the AI of HRMEC was significantly increased, indicating that a high concentration of glucose may increase the oxidative stress within the cell, activating the signal transduction pathway, promoting cell apoptosis. Leal et al. [32] found that the number of apoptotic cells significantly increased after HRMEC was treated with $30 \mathrm{mM}$ glucose, consistent with our result.
On the other hand, the concentration of $50 \mathrm{mM}$ to $150 \mathrm{mM}$ glucose exhibits inhibition on the cell variability of RGCs at $24 \mathrm{~h}, 48 \mathrm{~h}$, and $72 \mathrm{~h}$. Immunofluorescence staining revealed that the proportion of RGCs with neurite extensions was significantly lower in the $50 \mathrm{mM}, 100 \mathrm{mM}$, and $150 \mathrm{mM}$ groups than that in the control group $(5.5 \mathrm{mM})$ at $48 \mathrm{~h}$. The TUNEL assay also found that AI is significantly higher in the $50 \mathrm{mM}, 100 \mathrm{mM}$, and $150 \mathrm{mM}$ groups, indicating $50 \mathrm{mM}$ may be taken as the cutoff value for in vitro study of neuronal degeneration under hyperglycemia, and $50 \mathrm{mM}$ $100 \mathrm{mM}$ may be the proper concentration to stimulate diabetic microvasculopathy.

In the present study, we found that glucose concentration was positively correlated with the cell permeability of HRMEC. This may due to the decreased expression levels of cell tight junction proteins [33]. Extremely high glucose concentrations $(100 \mathrm{mM})$ can significantly inhibit cell proliferation. However, we cannot ignore the effect of osmotic pressure on cell biological behavior at this concentration. These results suggest that the extremely high glucose concentrations may not be suitable for in vitro testing. By contrast, considering the behavior of the HRMEC under different glucose concentrations, $25 \mathrm{mM}-50 \mathrm{mM}$ may be of the appropriate range and can be further applied in further in vitro study such as drug interventions for DR.

HRMEC has an important role in the maintenance of the normal function of RBB in human. Its pathological changes are the basis of diabetic microvasculopathy [34]. Our study investigated the gradient of glucose concentration and osmotic pressure on the biological behavior of HRMEC in vitro. The results have provided new insight into this area.

Previous studies have found a significantly lower cell proliferation rate in cells treated with a glucose concentration of $25 \mathrm{mM}$ compared to cells treated with $5.5 \mathrm{mM} \mathrm{[32,}$ 35]. However, Sun et al. found that $25 \mathrm{mM}$ glucose concentration promoted cell proliferation, migration, and apoptosis, consistent with our findings [36]. In our study, we have shown that increased osmotic pressure does not affect the biological behavior of HRMEC, which was consistent with 
previous studies that osmotic pressure did not affect cell viability at all, but some studies concluded that osmotic pressure of $25 \mathrm{mM}$ had a negligible effect on the biological behavior of HRMEC [37-39].

The best concentration of $\mathrm{D}$-glucose to use in human cell cultures to mimic the diabetic condition is yet to be set up. Furthermore, the concentration of D-glucose concentration will vary accordingly based on different cell lines. In the current study, we investigated for the first time the effects of the concentration gradient of glucose and osmotic pressure on the biological behavior of HRMEC, providing the rational concentration of D-glucose to mimic the $\mathrm{DR}$ condition. We found that $25 \mathrm{mM}$ (the cutoff value) to $50 \mathrm{mM}$ (the extreme value) is a suitable high glucose concentration.

To further analyze the effects and mechanisms of high sugar on HREMC biological behavior, we carried out a tube formation assay, a fast, quantifiable method to detect the angiogenic activity of HRMEC [40]. The advantages of this assay are that it is relatively easy to set up, requires a short culture period, is quantifiable, and is amenable to highthroughput analysis. HRMECs treated with $25 \mathrm{mM}$ or $50 \mathrm{mM}$ glucose have a larger angiogenic capacity than those treated with $5.5 \mathrm{mM}$ glucose. This result suggested a potential biological basis of abnormal neovascularization in DR patients. We also found that the quantification results of the tube formation assay are concomitant with the elevated protein expression of VEGFA. This finding suggested that VEGFA may be the key regulator for the high glucoseinduced angiogenesis process and established the rationality of $25 \mathrm{mM}-50 \mathrm{mM}$ glucose concentration for the in vitro hyperglycemia model.

In this study, we found that the cell variability of RGCs is significantly lower in the $50 \mathrm{mM}$ to $150 \mathrm{mM}$ and the linear declined trend was evidence from $5.5 \mathrm{mM}$ to $150 \mathrm{mM}$, which is consistent with previous studies [41]. RGCs were further labeled with neurons and RGC-specific markers TUJ1 and BRN3A, respectively, followed by the ImageJ quantitative analysis [42]. Immunofluorescence staining revealed that the proportion of RGCs with neurite extensions was significantly lower in the $50 \mathrm{mM}(p<0.05), 100 \mathrm{mM}(p<0.05)$, and $150 \mathrm{mM}(p<0.05)$ groups in comparison with that in the control group $(5.5 \mathrm{mM})$ at $48 \mathrm{~h}$. the AI is significantly higher in the $50 \mathrm{mM}(p<0.001), 100 \mathrm{mM} \quad(p<0.001)$, and $150 \mathrm{mM}$ $(p<0.001)$ groups compared to the control $5.5 \mathrm{mM}$ at $48 \mathrm{~h}$. The results indicate that $50 \mathrm{mM}-100 \mathrm{mM}$ may be used as the hyperglycemia in vitro model, and $50 \mathrm{mM}$ and $150 \mathrm{mM}$ may be taken as the cutoff and extreme value.

In this study, we set the hyperosmotic control group by artificially changing the osmotic pressure in the cell culture medium: Mannitol was added to the $5.5 \mathrm{mM}$ group to adjust the osmotic pressure to correspond with the same osmotic pressure of G25, G50, G100, and G150, thus forming M25, M50, M100, and M150 (mannitol concentrations 19.5, 44.5, 94.5, and $133.5 \mathrm{mmol} / \mathrm{l}$, respectively). The osmosis pressure of the control group (Con-5.5) was about $320 \mathrm{mOsm}$. According to the permeable pressure calculation formula, it can be obtained that the remaining groups of osmosis pressure were approximately $340 \mathrm{mOsm}$ (G25/M25), $365 \mathrm{mOsm}$ (G50/M50), $415 \mathrm{mOsm}$ (G100/M100), and $465 \mathrm{mOsm}$ (G150/M150). In our study, we have shown that increased osmotic pressure does not affect the biological behavior of RGCs from $25 \mathrm{mM}$ to $50 \mathrm{mM}$.

Our previous studies have shown that neurodegeneration is an earlier pathological change in the retina than microvasculopathy. It is interesting to study further the interactions between retinal endothelium cells and neurons. This study provides a basis for the next step in exploring how gene transfection can rescue vascular disease and early neuropathy. As the Müller glia are also involved in DR and are a component in the neuronal vascular unit, further studies warrant setting up more complicated in vitro models to stimulate the retinal neural vascular unit.

We used the healthy HRMECs and RGCs for establishing the in vitro model of DR. As the endothelial and neuronal cells in advanced DR stages may react differently to the $25-50 \mathrm{mM}$ or $50-100 \mathrm{mM}$ of glucose, respectively, this in vitro model may more applicable to stimulate the early stage of DR or even the preclinical stage of DR. This in vitro model also represents a valid tool useful for pathological investigation, drug screenings, and gene therapy of DR.

US-FDA approved Voretigene neparvovec-rzyl (Luxturna) gene therapy in 2017 to rescue the apoptotic photoreceptors in Leber's congenital amaurosis $[43,44]$. This led to the bright prospects of gene therapy on multigene eye diseases, including DR. Currently, 12 serotypes of adenoassociated virus have been applied as gene vectors. It is necessary to test the cell-specific serotype in vitro, especially in pathological conditions (high glucose) first [45]. Therefore, the establishment of proper hyperglycemia in vitro model is essential for further study of DR.

Due to the complexity of the internal environment and the diversity of the microenvironment, the application of animal models for investigating diabetic retinopathy faces great limitations and challenges. Therefore, the in vitro study could provide insight for studying the pathogenesis, progression, and even drug intervention of retinal diseases.

In conclusion, glucose of $25 \mathrm{mM}$ to $50 \mathrm{mM}$ is the appropriate range and $100 \mathrm{mM}$ extreme value of hyperglycemia for HRMEC in vitro; $50 \mathrm{mM}$ and $150 \mathrm{mM}$ are the proper range for RGCs. The impact of osmotic in higher glucose can be omitted. High glucose-induced VEGF is the key pathogenic factor of angiogenesis in endothelial cells.

\section{Abbreviations}

AI: $\quad$ Apoptosis index

BRB: Blood retinal barrier

BSA: Bovine serum albumin

CCK-8: Cell Counting Kit-8

DMEM: Dulbecco's modified Eagle's medium

DR: Diabetic retinopathy

ELISA: Enzyme-linked immunosorbent assay

FITC: $\quad$ Fluorescein Isothiocyanate

FBS: $\quad$ Fetal bovine serum

HBSS: Hank's balanced salt solution

HRMEC: Human retinal microvascular endothelial cell

OD: Optical density

PBS: $\quad$ Permeabilization solution 
PI: $\quad$ Propidium iodide

RMEC: Retinal microvascular endothelial cell

RGCs: Retinal ganglion cells

TUJ1: $\quad$ Antineuronal class III $\beta$-tubulin

VEGFA: Vascular endothelial growth factor-A.

\section{Data Availability}

All data generated or analyzed during this study are included in this published article.

\section{Disclosure}

All authors make sure that all data and materials as well as software application or custom code support, their published claims and comply with field standards.

\section{Conflicts of Interest}

All authors in this work have no financial and personal relationships with other people or organizations that could inappropriately influence (bias) the work.

\section{Authors' Contributions}

All authors have contributed to manuscript writing. All authors read and approved the final manuscript. The corresponding author managed all communication between the journal and all coauthors, before and after publication. The disclosures, declarations, and transparency on data statements from all authors are included in the manuscript as appropriate. We have provided transparency on reuse of material and mention of any unpublished material (for example manuscripts in press) included in the manuscript in a cover letter to the editor.

\section{Acknowledgments}

This work was supported by the National Natural Science Foundation of China (grants 81570850, 81170859, and 82070988) and the Ministry of Science and Technology Foundation of China (grant 2016YFC1305604).

\section{Supplementary Materials}

Supplemental Figure 1: cell migration ability detected by scratch assay. Compared to the control group, at $24 \mathrm{~h}$ of culture, higher cell migration rate was observed in the G25 and G50 groups, while lower in the G100 and M100 groups. Similar effect was observed at $48(p<0.05)$ and $72 \mathrm{~h}(p<0.01)$. (A1-A7) The images of the scratches at $0 \mathrm{~h}, 24 \mathrm{~h}$ (A8-A14), $48 \mathrm{~h}$ (A15-A21), and $72 \mathrm{~h}$ (A22-A28). (B1-B3) Cell migration rate in cells treated with different groups at 24,48 , and $72 \mathrm{~h}$. Con-5.5, G25-G100: concentration of glucose $(5.5,25,50$, and $100 \mathrm{mmol} / \mathrm{l}$, respectively); M25-M100: concentration of M-mannitol $(19.5,44.5$, and $94.5 \mathrm{mmol} / \mathrm{l}$, respectively). Scratch assay was examined under an inverted fluorescence microscope with a $\times 4$ objective. Scale bar: $200 \mu \mathrm{m}$ (A). ${ }^{*} p<0.05 ;{ }^{* *} p<0.01$. Supplemental Figure 2: representative composite images showing morphological changes of selected HREMCs detected with dual staining of Hoechst33342/PI. Green arrows: (1) viable cells with normal nuclei and (2) cells with apoptotic nuclei which was labeled by Hoechst33342. White arrows: (1) dead cells with normal nuclei and (2) dead cells with apoptotic nuclei which was labeled by PI. Yellow arrows: dead cells with apoptotic nuclei which were labeled by PI and Hoechst33342. Con-5.5, G25G100: concentration of glucose $(5.5,25,50$, and $100 \mathrm{mmol} / \mathrm{l}$, respectively); M25-M100: concentration of M-mannitol $(19.5,44.5$, and $94.5 \mathrm{mmol} / \mathrm{l}$, respectively). Cells were imaged by fluorescence microscope (magnification $\times 100$ ). AI: apoptosis index: the number of PI-positive cells/the number of Hoechst-stained cells. HRMEC: human retinal vascular endothelial cells. PI: propidium iodide. Scale bar: $200 \mu \mathrm{m}$ (A). ${ }^{*} p<0.05 ;{ }^{* *} p<0.01$. Supplemental Figure 3: HRMEC permeability evaluated by the FITC-labeled BSA method in different groups. After $24 \mathrm{~h}$ of cell culture, cell permeability slightly increased with the increase of glucose concentration. No significant effect on cell permeability was observed in the mannitol-control groups. Con-5.5, G25-G100: concentration of glucose $(5.5,25,50$, and $100 \mathrm{mmol} / \mathrm{l}$, respectively); M25-M100: concentration of M-mannitol (19.5, 44.5, and $94.5 \mathrm{mmol} / \mathrm{l}$, respectively). ${ }^{*} p<0.05 ;{ }^{* *} p<0.01$. Supplemental Figure 4: the protein expression analysis of VEGFA in different groups using ELISA. Compared to the control group, increased VEGF expression at 24, 48, and $72 \mathrm{~h}$ was found in the G25 group. (A-C) VEGFA expression in HRMECs treated with different groups at 24,48 , and $72 \mathrm{~h}$. Con-5.5, G25, and G50: concentration of glucose $(5.5,25$, and $50 \mathrm{mmol} / \mathrm{l}$, respectively). VEGFA: vascular endothelial growth factor-A. ELISA: enzyme-linked immunosorbent assay. ${ }^{*} p<0.05 ;{ }^{* *} p<0.01$. Supplemental Figure 5: representative immunofluorescence images of RGCs in different groups at $48 \mathrm{~h}$. RGCs were positively stained with TUJ1 (green, A1-A9, yellow arrows), DAPI (blue, B1-B9, white arrows), and Brn3a (red, $\mathrm{C} 1-\mathrm{C}$, green arrows) which are neuronal-specific, nucleus, and RGC-specific markers, respectively. Merged images were presented as D1-D9. Con-5.5, G25-G150: concentration of glucose $(5.5,25,50$, 100 , and $150 \mathrm{mmol} / \mathrm{l}$, respectively); M25-M150: concentration of M-mannitol $(19.5,44.5,94.5$, and $133.5 \mathrm{mmol} / \mathrm{l}$, respectively). RGCs: retinal ganglion cells. Scale bar: $200 \mu \mathrm{m}(\mathrm{A}) .{ }^{*} p<0.05 ;{ }^{* *} p<0.01$. Supplemental Figure 6: apoptotic index of RGCs in different groups detected and quantified by the PI/Hoechst33342 fluorescence staining. RGCs were cultured and stained by the PI/Hoechst 33342 fluorescence staining at $24 \mathrm{~h}$ (A1-A9), $48 \mathrm{~h}$ (A10-A18), and $72 \mathrm{~h}$ (A19-A27). (B1-B3) AI in cells treated with different groups at 24, 48, and $72 \mathrm{~h}$. Quantification of apoptotic RGCs at $24 \mathrm{~h} \mathrm{(B1),} 48 \mathrm{~h}$ (B2), and $72 \mathrm{~h}$ (B3) by the ImageJ analysis. Compared to the control group, the AI of the G50, G100, and G150 groups was significantly higher after $24 \mathrm{~h}$ of cell culturing $(p<0.05)$. At $48 \mathrm{~h}$, the AI in the G50, G100, and G150 groups was significantly higher compared to that in the control group $(p<0.05)$. At $72 \mathrm{~h}$, the AI of the G50, G100, and G150 groups was significantly higher than that of the control group $(p<0.05)$. Green arrow indicates (1) viable cells with normal nuclei and (2) cells with apoptotic nuclei which was labeled by Hoechst33342. Yellow arrow 
indicates (1) dead cells with normal nuclei and (2) dead cells with apoptotic nuclei which was labeled by PI. White arrow indicates dead cells with apoptotic nuclei which was labeled by PI and Hoechst33342. Con-5.5, G25-G150: concentration of glucose $(5.5,25,50,100$, and $150 \mathrm{mmol} / \mathrm{l}$, respectively); M25-M150: concentration of M-mannitol (19.5, 44.5, 94.5, and $133.5 \mathrm{mmol} / \mathrm{l}$, respectively). RGCs: retinal ganglion cells, AI: apoptosis index: the number of PI-positive cells/the number of Hoechst-stained cells. Cells were imaged by fluorescence microscope (magnification $\times 100$ ). Scale bar: $200 \mu \mathrm{m}$ (A). ${ }^{*} p<0.05 ;{ }^{* *} p<0.01$. Supplemental Figure 7: representative immunofluorescence images and quantification of TUNEL-positive cells. TUNEL staining (green, A2E2), DAPI staining (blue, A1-E1), and merged image of RGCs with different treatments. Merged images were presented as A3-E3. Con-5.5, G25-G150: concentration of glucose $(5.5,25,50,100$, and $150 \mathrm{mmol} / \mathrm{l}$, respectively). Scale bar: $200 \mu \mathrm{m} \quad$ (A). ${ }^{*} p<0.05 ;{ }^{* *} p<0.01$. (Supplementary Materials)

\section{References}

[1] J. Cai and M. Boulton, "The pathogenesis of diabetic retinopathy: old concepts and new questions," Eye (Lond), vol. 16, no. 3, pp. 242-260, 2002.

[2] R. Simó, J. M. Sundstrom, and D. A. Antonetti, "Ocular antiVEGF therapy for diabetic retinopathy: the role of VEGF in the pathogenesis of diabetic retinopathy," Diabetes Care, vol. 37, no. 4, pp. 893-899, 2014.

[3] X. Zhang, S. Bao, B. D. Hambly, and M. C. Gillies, "Vascular endothelial growth factor-A: a multifunctional molecular player in diabetic retinopathy," The International Journal of Biochemistry \& Cell Biology, vol. 41, no. 12, pp. 2368-2371, 2009.

[4] E. A. Stewart, S. Saker, and W. M. Amoaku, "Dexamethasone reverses the effects of high glucose on human retinal endothelial cell permeability and proliferation _in vitro_," Experimental Eye Research, vol. 151, pp. 75-81, 2016.

[5] Y. Shi, C. Chen, Y. Xu, Y. Liu, H. Zhang, and Y. Liu, "LncRNA FENDRR promotes high-glucose-induced proliferation and angiogenesis of human retinal endothelial cells," Bioscience, Biotechnology, and Biochemistry, vol. 83, no. 5, pp. 869-875, 2019.

[6] H. Shi, T. W. Carion, Y. Jiang, J. J. Steinle, and E. A. Berger, "VIP protects human retinal microvascular endothelial cells against high glucose-induced increases in TNF- $\alpha$ and enhances RvD1," Prostaglandins \& Other Lipid Mediators, vol. 123, pp. 28-32, 2016.

[7] N. Wang, Y. Fan, and P. Ni, "High glucose effect on the role of CD146 in human proximal tubular epithelial cells in vitro," Journal of Nephrology, vol. 21, no. 6, pp. 931-940, 2008.

[8] X. Zhang, D. Lai, S. Bao, B. D. Hambly, and M. C. Gillies, “Triamcinolone acetonide inhibits p38MAPK activation and neuronal apoptosis in early diabetic retinopathy," Current Molecular Medicine, vol. 13, no. 6, pp. 946-958, 2013.

[9] L.-T. Liu, L. Liang, W. Wang et al., "Isolariciresinol-9'-O- $\alpha$-Larabinofuranoside protects against hydrogen peroxideinduced apoptosis of human umbilical vein endothelial cells via a PI3K/Akt/Bad-dependent pathway," Molecular Medicine Reports, vol. 17, 2018.

[10] W. Liu, X. Zhang, C. Song et al., "Expression and characterization of a soluble VEGF receptor 2 protein," Cell \& Bioscience, vol. 4 , no. $1,2014$.
[11] Y. Zhou, J. Yuan, C. Qi, X. Shao, S. Mou, and Z. Ni, "Calcium dobesilate may alleviate diabetes-induced endothelial dysfunction and inflammation," Molecular Medicine Reports, vol. 16, no. 6, pp. 8635-8642, 2017.

[12] J. Liu, G. Miao, B. Wang et al., “_Chlamydia pneumoniae_ infection promotes monocyte transendothelial migration by increasing vascular endothelial cell permeability _via_ the tyrosine phosphorylation of VE-cadherin," Biochemical and Biophysical Research Communications, vol. 497, no. 2, pp. 742-748, 2018.

[13] P. Che, J. Liu, Z. Shan et al., "miR-125a-5p impairs endothelial cell angiogenesis in aging mice via RTEF-1 downregulation," Aging Cell, vol. 13, no. 5, pp. 926-934, 2014.

[14] S.-i. Miura, Y. Matsuo, and K. Saku, "Transactivation of KDR/Flk-1 by the $\mathrm{B} 2$ receptor induces tube formation in human coronary endothelial cells," Hypertension, vol. 41, no. 5, pp. 1118-1123, 2003.

[15] L. A. Mesentier-Louro, C. Zaverucha-do-Valle, A. J. da SilvaJunior et al., "Distribution of mesenchymal stem cells and effects on neuronal survival and axon regeneration after optic nerve crush and cell therapy," PLoS One, vol. 9, no. 10 article e110722, 2014.

[16] K. Kashiwagi, Y. Iizuka, Y. Tanaka, M. Araie, Y. Suzuki, and S. Tsukahara, "Molecular and cellular reactions of retinal ganglion cells and retinal glial cells under centrifugal force loading," Investigative Ophthalmology \& Visual Science, vol. 45, no. 10, pp. 3778-3786, 2004.

[17] J. Wu, H. K. Mak, and Y. K. Chan, "An _in vitro_pressure model towards studying the response of primary retinal ganglion cells to elevated hydrostatic pressures," Scientific Reports, vol. 9, no. 1, 2019.

[18] G. R. Musada, G. Dvoriantchikova, C. Myer, D. Ivanov, S. K. Bhattacharya, and A. S. Hackam, "The effect of extrinsic $\mathrm{Wnt} / \beta$-catenin signaling in Muller glia on retinal ganglion cell neurite growth," Developmental Neurobiology, vol. 80, no. 3-4, pp. 98-110, 2020.

[19] K. Omodaka, T. Kurimoto, and O. Nakamura, "Artemin augments survival and axon regeneration in axotomized retinal ganglion cells," Journal of Neuroscience Research, vol. 92, no. 12, pp. 1637-1646, 2014.

[20] D.-Y. Yu, S. J. Cringle, C. Balaratnasingam, W. H. Morgan, P. K. Yu, and E.-N. Su, "Retinal ganglion cells: energetics, compartmentation, axonal transport, cytoskeletons and vulnerability," Progress in Retinal \& Eye Research, vol. 36, pp. 217-246, 2013.

[21] E. Kaplan and E. Benardete, "Chapter 2 The dynamics of primate retinal ganglion cells," Progress in Brain Research, vol. 134, 2001.

[22] B. Alberts, Molecular Biology of the Cell, Garland Science, New York, 2008.

[23] V. Paulette and V. Pierre, Discovering Life, Manufacturing Life: How the Experimental Method Shaped Life Sciences, Springer, Berlin, 2010.

[24] J. Nairn and N. C. Price, Exploring Proteins: a Student's Guide to Experimental Skills and Methods, Oxford University Press, America, 2009.

[25] A. Bertero, J. Augustyniak, L. Buzanska, and F. Caloni, "Species-specific models in toxicology: in vitro epithelial barriers," Environmental Toxicology and Pharmacology, vol. 70, p. 103203, 2019.

[26] N. Quignot, J. Hamon, and F. Bois, Extrapolating in vitro results to predict human toxicity, Springer, New York, 2014. 
[27] N. G. Hattangady and M. S. Rajadhyaksha, "A brief review of in vitro models of diabetic neuropathy," International Journal of Diabetes in Developing Countries, vol. 29, no. 4, pp. 143-149, 2009.

[28] A. Matteucci, M. Varano, C. Mallozzi et al., "Primary retinal cultures as a tool for modeling diabetic retinopathy: an overview," Biomed Research International, vol. 2015, Article ID 364924, 16 pages, 2015.

[29] A. Zambrano, E. Jara, and P. Murgas, "Cytokine stimulation promotes increased glucose uptake via translocation at the plasma membrane of GLUT1 in HEK293 cells," Journal of Cellular Biochemistry, vol. 110, no. 6, pp. 1471-1480, 2010.

[30] Y. Song, Y. Du, W. Zou, Y. Luo, X. Zhang, and J. Fu, "Involvement of impaired autophagy and mitophagy in Neuro-2a cell damage under hypoxic and/or high-glucose conditions," Scientific Reports, vol. 8, 2018.

[31] Y. Wang, Y. Zhou, L. Xiao, S. Zheng, N. Yan, and D. Chen, "E2f1 mediates high glucose-induced neuronal death in cultured mouse retinal explants," Cell cycle, vol. 16, no. 19, pp. 1824-1834, 2017.

[32] E. C. Leal, C. A. Aveleira, Á. F. Castilho et al., "High glucose and oxidative/nitrosative stress conditions induce apoptosis in retinal endothelial cells by a caspase-independent pathway," Experimental Eye Research, vol. 88, no. 5, pp. 983-991, 2009.

[33] S. Roy, J. X. Jiang, A.-F. Li, and D. Kim, "Connexin channel and its role in diabetic retinopathy," Progress in Retinal and Eye Research, vol. 61, pp. 35-59, 2017.

[34] A. P. Adamis, J. W. Miller, M.-T. Bernal et al., "Increased vascular endothelial growth factor levels in the vitreous of eyes with proliferative diabetic retinopathy," American Journal of Ophthalmology, vol. 118, no. 4, pp. 445-450, 1994.

[35] Y. Qiao, C. L. Fan, and M. K. Tang, “Astragaloside IV protects rat retinal capillary endothelial cells against high glucoseinduced oxidative injury," Drug Design, Development and Therapy, vol. Volume 11, pp. 3567-3577, 2017.

[36] J. Sun, Y. Xu, and H. Deng, "Intermittent high glucose exacerbates the aberrant production of adiponectin and resistin through mitochondrial superoxide overproduction in adipocytes," Journal of Molecular Endocrinology, vol. 44, no. 3, pp. 179-185, 2010.

[37] J.-H. Wu, Y.-H. Wang, W. Wang et al., "MiR-18b suppresses high-glucose-induced proliferation in HRECs by targeting IGF-1/IGF1R signaling pathways," International Journal of Biochemistry \& Cell Biology, vol. 73, pp. 41-52, 2016.

[38] Y. Zeng, Z. Cui, J. Liu, J. Chen, and S. Tang, "MicroRNA-29b$3 p$ promotes human retinal microvascular endothelial cell apoptosis via blocking SIRT1 in diabetic retinopathy," Frontiers in Physiology, vol. 10, 2020.

[39] F. Qiu, H. Tong, Y. Wang, J. Tao, H. Wang, and L. Chen, "Inhibition of miR-21-5p suppresses high glucose-induced proliferation and angiogenesis of human retinal microvascular endothelial cells by the regulation of AKT and ERK pathways via maspin," Bioscience, Biotechnology, and Biochemistry, vol. 82, no. 8, pp. 1366-1376, 2018.

[40] Z. Zhao, X. Ma, J. Ma, X. Sun, F. Li, and J. Lv, "Naringin enhances endothelial progenitor cell (EPC) proliferation and tube formation capacity through the CXCL12/CXCR4/PI3K/Akt signaling pathway," Chemico-Biological Interactions, vol. 286, pp. 45-51, 2018.

[41] H.-Y. Chen, Y.-J. Ho, H.-C. Chou et al., "The role of transforming growth factor-beta in retinal ganglion cells with hyperglycemia and oxidative stress," International Journal of Molecular Sciences, vol. 21, no. 18, p. 6482, 2020.

[42] A. Ebneter, "Protection of retinal ganglion cells and the optic nerve during short-term hyperglycemia in experimental glaucoma," Archives of ophthalmology, vol. 129, no. 10, pp. 13371344, 2011.

[43] J. J. Darrow, "Luxturna: FDA documents reveal the value of a costly gene therapy," Drug Discov Today, vol. 24, no. 4, pp. 949-954, 2019.

[44] M. Stopa, "Gene therapy prospects in ophthalmology," Klin Oczna, vol. 104, no. 3-4, pp. 289-292, 2002.

[45] R. Li, Y. Qu, Y. Liu, A. F. Noor, and J. Tran, "Characteristics and advantages of adeno-associated virus vector-mediated gene therapy for neurodegenerative diseases," Neural Regeneration Research, vol. 14, no. 6, pp. 931-938, 2019. 